\title{
SOCIAL AND REGIONAL ASPECTS OF HOUSING SITUATION IN LITHUANIA
}

\author{
Vytautas JONAITIS and Jurga NAIMAVIČIENE் \\ Department of Construction Economics and Property Management, Vilnius Gediminas Technical University, \\ Sauletekio al. 11, LT-10223 Vilnius-40, Lithuania \\ E-mail: V.Jonaitis@aplinkuma.lt; Email: Jurga.Naimauiciene@st.vtu.lt
}

Received 2 July 2004; accepted 15 October 2004

\begin{abstract}
With respect to the assessment of Lithuanian housing situation in the context of other EU countries, it is important to consider it more thoroughly in social and regional aspects. It is also necessary to evaluate the situation on a scale of emerging housing problems and specify the strategic trends as well as goals to deal with these problems. This article discusses the following issues: social and regional aspects of housing and the quality of it; the possibility to obtain or rent a home in the context of current market situation; State financial support for housing; sociological assessment of living conditions.
\end{abstract}

KEYWORDS: Social home; Households; State financial support for housing, Lithuania

\section{INTRODUCTION}

When the Republic of Lithuania regained its independence a completely new treatment of homeownership and housing fund structure was introduced. The data obtained from the general inhabitants registration carried out in 1989 indicated that $69.1 \%$ of all homeowners were State, cooperative and public organizations and just $30.9 \%$ of them were natural persons. Whereas at present Lithuania is among the European states representing the greatest achievements in home privatization. The data obtained from the general inhabitants registration carried out in 2001 indicated that $95.2 \%$ of homeowners were natural persons, $2.9 \%$-Local Government or State itself, $1.8 \%$ - private legal persons.

After the implementation of the Land Reform, individual house owners gained ownership of the parcels of land assigned to these houses [4].

Apartment house tenants became actual owners of their flats and gained corporate partial ownership right to general use objects (house constructions, facilities, general use premises) and the parcel of land assigned to the house (provided that the land had been assigned to the house and the ownership right to it had been given on the basis of common agreement).

There is a large amount of available capacity in the industry to respond to an increase in the demand for residential construction. For example, the Lithuanian Builders Association estimates that the building industry could build 20,000 dwelling units a year L1J.

These changes have established the real estate market and initiated an increase in choice possibilities and a possibility to build a house according to one's preferences.

According to the Civil Code of the Republic of Lithuania, new owners of apartment houses have to establish owners' communities and make joint activity agreements encompassing common property control and maintenance. 
However, only a quarter of all apartment houses have established such communities. The rest of apartment houses are under control of the administrators (private or Local Government Apartment Economy enterprises) appointed by the Local Governments.

Apartment houses in EU member states are under control of flat owners' communities or cooperatives and associations, founded by such communities or cooperatives. Whereas the non-profit enterprises established by such cooperatives are responsible for the technical maintenance services. The activity of these enterprises is under the supervision of the actual service consumers.

The evidence indicates that it is necessary not only to establish the legal basis for housing, but also to stimulate the process of social adaptation, develop owner's self-awareness, educate housing subjects, and promote the delivery of information to the general public.

The establishment of the housing control and maintenance system based on the EU model and the development of the discussed communities and organizations will be among the most topical issues of the integration process [2].

\section{SOCIAL AND REGIONAL ASPECTS OF HOUSING AND ITS QUALITY}

The data obtained from the general population and housing registration carried out in 2001 allow specifying the Lithuanian housing situation in various aspects.

Population distribution based on the housing type, i.e. the proportion of population living in individual houses, apartment houses, hostels, residential hotels, and shelters unfit for people to live in (huts, summer-houses etc.), acts as a housing situation indicator (Table 1 ). It reveals the distribution of living conditions and the level of total homelessness.

According to the data obtained from the registration, almost $99.0 \%$ of all inhabitants in Lithuania live in traditional types of homes $(38.1 \%$ in individual low-rise houses and $60.9 \%$ - in apartment houses). One percent (17 400) resided in hostels and residential hotels, $0.04 \%$ (1 250) - in shelter unfit for people to live in (huts, summerhouses etc) [6].

This rate shows the relatively low level of complete homelessness. The rate is much higher in other EU states. This is conditioned by the still prevailing settled lifestyle of the majority of Lithuanians.

If persons who do not own or rent permanent home and reside in the homes of acquaintances, relatives, and parents were considered as homeless, the number of the homeless Lithuanians would be relatively high.

The household investigation carried out in 2002 revealed the approximate number of the homeless. It was determined that approximately $5.6 \%$ of households (single persons or families) were residing in a room of a common use flat or hostel. Thus, it can be calculated that approximately $73 \quad 000$ households/ 200000 inhabitants did not own a home [3].

The housing rate was proved to be different for town and village areas. According to the registration data, $21.2 \mathrm{~m}^{2}$ of living space fell to one inhabitant in town area $\left(20.4 \mathrm{~m}^{2}\right.$-in Vilnius city), $25.4 \mathrm{~m}^{2}$ - in village area $\left(30-32 \mathrm{~m}^{2}\right.$ - in Ignalina and Molètai regions) [6].

Table 1. Population distribution based on the home types and determined on the basis of the data obtained from the general population and housing registration carried out in 2001 [6]

\begin{tabular}{llll}
\hline Home type & Whole Country, & From them & \\
\cline { 3 - 4 } & $\%$ & City area, \% & Village area, \% \\
\hline Individual house or a part of it & 38,1 & 19,7 & 80,2 \\
Flat in an apartment house & 60,86 & 79,0 & 19,4 \\
Hostels, residential hotels & 1,0 & 1,3 & 0,4 \\
Shelter unfit for people to live in & 0,04 & NA & NA \\
\hline
\end{tabular}

NA - no available data 
Table 2. Energy, water and other home utilities according to the public population and housing registration carried out in 2001 [6]

\begin{tabular}{llll}
\hline Utilities & Country, \% & From them \\
\cline { 2 - 4 } & & City area, \% & Village area, \% \\
\hline Water-supply & 78.9 & 91.9 & 50.6 \\
Sewerage & 76.3 & 90.7 & 45.1 \\
Hot water & 67.4 & 83.8 & 31.8 \\
Bathroom/shower & 71.8 & 87.0 & 38.9 \\
Toilet with the effluent water & 70.8 & 88.0 & 33.4 \\
Electricity & 99.7 & 99.8 & 99.3 \\
Stationary stove (gas, electric) & 94.2 & 97.7 & 86.7 \\
Kitchen & 98.8 & 99.0 & 98.5 \\
Central or local heating & 72.0 & 92.5 & 49.6 \\
\hline
\end{tabular}

Most of the inhabitants in the city areas (79\%) resided in apartment houses, $19.5 \%$ - in individual houses or in their parts, $19.4 \%$ - in apartment houses, $0.4 \%$ - in hostels. Hence, the living environment was more individualized in the village area and more socialized in the town area.

Home in the village area was proved to be more ecological and more spacious. The level of the village areas' supply with the utilities appeared to be comparatively low.

Only half of the village homes had water supply and sewerage (including local one), just a third - hot water and bathroom/shower.

Most of the houses in this area were built 50 or even more years ago and reflected deterioration.

The data once again substantiates the conclusion of this research stating that striving for town and village convergence it is especially important to develop the construction of individual houses in town areas, while village areas demand renovation and the establishment of technological infrastructure.
The control and maintenance of a home, as a juridical object of tangible property, mainly depends on the legal relation of the inhabitants to their home.

\section{THE SOCIOLOGICAL EVALUATION OF LIVING CONDITIONS}

The data obtained from the household research carried out in 2002 enables the evaluation of the living conditions in Lithuania from the sociological point of view. We will discuss the evaluation of the current living conditions, their change over the past five years and the future forecast for the coming three years.

The investigation revealed that only $42.8 \%$ of households consider their living conditions to be very good, $47.0 \%$ - satisfactory and $10.2 \%$ - bad or very bad.

This type of evaluation proves that the issue of living conditions in Lithuania is very relevant.

The investigation enabled the determination of more significant living conditions' parameters

Table 3. Evaluation of the living conditions according to the research data obtained from the investigation of the households in 2002 [3]

\begin{tabular}{ll}
\hline Living conditions & Respondents (from total $100 \%$ ), \% \\
\hline Very good & 4,3 \\
Good & 38,5 \\
Satisfactory & 46,9 \\
Bad & 8,9 \\
Very bad & 1,1 \\
No response & 0,3 \\
\hline
\end{tabular}


Table 4. The change in the living conditions over the past five years [3]

\begin{tabular}{ll}
\hline Expected change & Respondents (from total $100 \%$ ) \\
\hline Anticipate improvement & 22,3 \\
No change & 59,4 \\
Anticipate deterioration & 14,7 \\
Do not know & 3,6 \\
\hline
\end{tabular}

with respect to the home location, living space, layout, utilities, and heating effectiveness.

The households appeared to be most discontent with the heating effectiveness (50.8\%). $23.2 \%$ were discontent with the utilities, $21.1 \%$ - with the layout, $20.1 \%$ - with the living space.

The largest part of those who were discontent with the heating resided in apartment houses (59.6\%). $34.5 \%$ of all persons living in individual houses were also discontent with the heating. The largest part of those who were discontent with the living space also resided in apartment houses (30.2\%).

The least satisfied with the living conditions were the elderly households on a low income and residing in village areas. More discontent were those who lived in flats with shared kitchens and those who lived in hostel type of houses.

Thus, it appears that in order to achieve higher standards of living conditions it is necessary to consider the increase of the heating effectiveness, the improvement of heat insulation, the expansion of utilities in village areas and renovation of apartment houses as primary goals.

The data obtained from the investigation indicated that respondents were more optimistic about their future than the past. $22.3 \%$ of all respondents thought that their living conditions would improve over the coming three years, $14.7 \%$ - living conditions would worsen [3].
Households anticipated more positive than negative changes. Those having optimistic point of view amounted $7.6 \%$ more than those households who were pessimistic about the future.

The most optimistic were young, up to 40 years old households who were leading their own business or a permanent job. The least optimistic were the elderly, over 60 year-old households, pensioners, the disabled and other persons, not capable to work.

\section{POSSIBILITY TO OBTAIN OR RENT A HOME IN THE MARKET}

The most realistic way of housing or its improvement is building or renting a home in the market.

The possibility to build or rent a home in the market depends on inhabitants' income, prices and variety of the supply. It is necessary to obtain the data of households' income distribution in order to be able to assess the possibilities of buying or renting a home in the market.

The investigation revealed that the range of the difference of households' income is very large. The income of the first decimals differs 12-15 times from the income of the last decimal. Pensioners, the disabled, the homeless, large families, and village area households occupy the first, second, and third decimals.

Table 5. Household's income distribution in decimals according to the data obtained from the investigation of households in 2002 [3]

\begin{tabular}{llllllllll}
\hline \multicolumn{7}{l}{ Gross Income, Lt/Month according to Decimals } \\
\hline 1 & 2 & 3 & 4 & 5 & 6 & 7 & 8 & 9 & 10 \\
\hline $251-300$ & $451-500$ & $601-700$ & $801-900$ & $901-$ & $1001-$ & $1251-$ & $1751-$ & $2001-$ & $3001-$ \\
& & & & 1000 & 1250 & 1500 & 2000 & 2500 & 5000 \\
\hline
\end{tabular}


Table 6. Prevailing home rent or purchase prices in the market ( $1 \mathrm{~m}^{2}$ estimated in Litas), 2002 [4]

\begin{tabular}{|c|c|c|c|c|c|}
\hline & \multicolumn{5}{|l|}{ Areas } \\
\hline & Vilnius & Kaunas & Klaipèda & Siauliai & Panevẻžys \\
\hline \multicolumn{6}{|l|}{ A. Price of a home } \\
\hline $\begin{array}{l}\text { I. town centre and } \\
\text { prestigious areas }\end{array}$ & $3000-5000$ & 2000 & 2500 & 1200 & 1000 \\
\hline $\begin{array}{l}\text { 2. areas of apartment } \\
\text { houses }\end{array}$ & $1800-2000$ & $1300-1500$ & $1500-2000$ & $800-900$ & $600-700$ \\
\hline \multicolumn{6}{|l|}{ B. Monthly rent } \\
\hline 1. town centre & $20-30$ & $8-10$ & $12-15$ & $4-5$ & $3-4$ \\
\hline $\begin{array}{l}\text { 2. Areas of apartment } \\
\text { houses }\end{array}$ & $10-12$ & $5-6$ & $8-9$ & $2-3$ & 2 \\
\hline
\end{tabular}

Younger, up to 40 years old, leading their own business and well paid job households occupy the last two decimals.

This income distribution determines different possibilities and demands. The difference in the possibilities was revealed in the social economical self-evaluation that was made by the respondents. $5.2 \%$ of households assigned themselves to the upper social class, $28.8 \%$ - to the middle class, 40.8 $\%$ - to the lower middle social class, and $21.0 \%$ - to the deprived [3].

The households' possibilities to buy or rent a home in the market can be determined relating the income to the purchase or rent prices available in the market.

The comparison of income distribution and the prices suggest a conclusion that only those occupying 7-10 decimals, i.e. households assigning themselves to the upper and upper middle classes (approximately $34 \%$ of all households), can afford buying or renting a home in the largest Lithuanian cities housing $50 \%$ of all country population.

The households occupying 1-3 decimals and assigning themselves to the deprived can afford just a cheap social home, rented according to the noncommercial rent rate established by the local governments. The households occupying 4-7 decimals and assigning themselves to the lower middle social class can afford buying or renting a home in smaller towns and village areas or obtaining or renting a modest home in a bigger town if special state financial support is granted to them.
The poll revealed that in a case of increased income $19.4 \%$ of households would buy a better home, $3.6 \%$ - would build a house, and $2.4 \%$ would rent a better home. Up to 40 years old and engaged in business activity households or households on a high income are willing more than others to improve their living conditions.

Favorable development of the housing loan market increases chances to obtain or build a home.

Starting from 2002 Lithuanian banks have been offering very favorable long-term loans for 25 or longer periods with 4-5\% annual interest rate (most of EU member states offer 6-7 \% interest rate). Thus, the number of loans given increased twice in 2003 if compared to the previous year.

The growth of Lithuanian banks and economy will likely initiate the rapid development of the home loan market and respectively increase the possibilities to take these loans.

In order to increase the availability of home loans it is important to develop the policy of granting certain State financial support to households with insufficient income.

\section{STATE FINANCIAL SUPPORT FOR HOUSING}

State financial support for housing has been granted since 1992 observing the Population Maintenance Law.

Preferential loans having 5\% annual inter- 
est were being granted until 1998. Then banks (upon their request) became responsible for granting credits, while the State budget funds were covering the difference between the bank interest rates and the discussed preferential rates.

Additional privileges - full interest coverage and/or the subsidy for the coverage of a certain part of the credit taken (up to 20\%) were granted to the socially supported families or single persons (households). Socially supported households encompassed the following groups: the disabled grown-ups (I, II disability groups) and children, grown-up orphans (until 35 years old), persons suffering from the chronic diseases (from the list confirmed by the Ministry of Health), large families with four or more children, single mothers or fathers with two or more children, and pensioners if there are now employed persons in their households.

Ten thousand of households were granted preferential loans from 1993 until 2002.

Population Income-Tax Law came into force January 1, 2003. Since then, the regulations for the process of granting state financial support have changed completely. The support has been linked to the inhabitants' contributions to the State budget, their income, and property. The households have gained a right to the refunding of the income tax in a case a part of their fiscal year expenditure being devoted to covering bank interest for the granted housing credit for building or purchasing a home. This part of fiscal year expenditure is to be subtracted from the income tax.

Additional State financial support now covers only the households with the income and property lower than the amounts defined by the State Government: single person households with annual income not exceeding 24,000 Litas and property 40,000 Litas and families with annual income not exceeding 36,000 Litas and property - 80,000 Litas [3]. All of these households have a right to obtain a housing credit making a lower than established by the bank initial contribution. The smallest possible initial contribution $-5 \%$ of the being purchased home value has been set. These types of credits are being insured in the Housing Loans Insurance Company established by the State Government covering not less than $50 \%$ of the insurance contribution from the State budget. Besides, separate social groups (young families with one or more children, large families with three of more children) have a right to obtain State subsidy to cover a part of their housing loan (10\%). Families with a disabled person (I, II disability groups) or a disabled child, grownup orphans (up to 35 years old) have a right to obtain State subsidy to cover $20 \%$ of their housing loan.

These subsidies make housing loans available to the households with average income.

\section{THE DEMAND FOR SOCIAL HOME AND THE REALIZATION PERSPECTIVE}

Local Government homes rented on a noncommercial basis to persons and families with low income are treated as social homes.

Until January 1, 2003 all inhabitants had a right to rent a Local Government home if they owned no home or the living space of the premises where they resided was less than $10 \mathrm{~m}^{2}$ per capita. Three lists were established to register the ones willing to rent a home from the local Government: common list, the list of socially supported persons or young families (the age of each spouse not exceeding 35 years).

Socially supported families encompassed the disabled grown-ups (I, II disability groups) and children, grown-up orphans (until 35 years old), persons suffering from the chronic diseases (from the list confirmed by the Ministry of Health), large families with four or more children, single parent with two or more children, and pensioners if there were no employed persons in their households.

Early 2002 reflected 18730 households registered in the list for renting a Local Government home (early 2001 - 17141 households). Over 19932002 Local Governments rented homes for 6000 households [5]. However, the rows of the ones waiting to rent this type of 
Table 7. The Demand for Social Home according to the number of registered households having a right to social home (January 1, 2003) [7, 8]

\begin{tabular}{|c|c|c|c|c|c|}
\hline \multirow[b]{2}{*}{ Indicators } & \multirow[b]{2}{*}{ Total } & \multicolumn{2}{|c|}{ According to Social Groups } & \multirow[b]{2}{*}{ The Disabled } & \multirow[b]{2}{*}{ Others } \\
\hline & & Young families & Orphans & & \\
\hline $\begin{array}{l}\text { 1. Number of households } \\
\text { having a right to social home }\end{array}$ & 8550 & 3095 & 483 & 1406 & 3566 \\
\hline $\begin{array}{l}\text { 2. Distribution, } \% \\
\text { 3. From the total number } \\
\text { indicated in point } 1 \text { : }\end{array}$ & 100 & 36,2 & 5,6 & 16,4 & 41,8 \\
\hline $\begin{array}{l}\text { 3.1. Towns with Local } \\
\text { Governments ( } 12 \text { towns) }\end{array}$ & 4793 & 1945 & 327 & 807 & 1714 \\
\hline $\begin{array}{l}\text { 3.2. Districts } \\
\text { 4. Pereentage rate: }\end{array}$ & 3757 & 1150 & 156 & 599 & 1852 \\
\hline a. Towns & 100 & 40,6 & 6,8 & 16,8 & 35,8 \\
\hline b. Districts & 100 & 30,6 & 4,2 & 15,9 & 49,3 \\
\hline $\begin{array}{l}\text { 5. Demand for Social Home } \\
1000 \text { inhabitants: }\end{array}$ & & & & & \\
\hline 5.1. Towns & 3,1 & 1,25 & 0,2 & 0,55 & 1,10 \\
\hline 5.2. Districts & 1,95 & 0,60 & 0,1 & 0,3 & 0,95 \\
\hline 5.3. Vilnius & 3,9 & 1,30 & 0,3 & 0,6 & 1,70 \\
\hline
\end{tabular}

home remained the same.

It is obvious that the demand was much higher than the availability of these homes. This was conditioned by the lack of sufficient financing. The budgets of the Local Governments were unable to grant contributions for the development of social home, whereas the contributions from the State Budget were only fragmentai.

Law of State Financial Support for Housing came into force 1 January 2003. Since then, the right to the social home has been determined by the income and property of households.

A right to the social home is granted to the persons and families (households) who neither own a home nor rent it from the Local Government or those whose living space is less than $10 \mathrm{~m}^{2}$ per capita and their income and property do not exceed the

following amounts: - The disposable income and property of a single person living in Vilnius, Kaunas,

Klaipeda, Palanga and Neringa make up, respectively, 12,000 Litas and 20,000 Litas, the disposable income and property of a single person living elsewhere make up, respectively, - 9000 Litas and 15,000 Litas.
- The disposable income and property of families living in the mentioned areas make up, respectively, 24,000 and 40,000 Litas, disposable income and property of those living elsewhere make up, respectively, - 20,000 Litas and 30,000 Litas. This procedure is meant for granting support to the poorest households not capable of obtaining a home from the market.

The households having a right to the social home according to the Law are registered in the Local Governments.

The registration of the discussed households revealed the double decrease (compared to data obtained in 2002) in number of those having a right to social home since the inclusion of new income and property criteria in the Law of State Financial Support for Housing.

This change in demand enables the poorest households to solve their housing problems more effectively.

Young families comprise a big part of those having a right to social home (when the age of each spouse or a single parent does not exceed 35 years). They comprise $30.6 \%$ of the total structure and 40.6 $\%$ in towns. The disabled amount $16.4 \%$. The demand structures built 
according to the specific social groups needs allow determining a more specified social housing fund and offering a greater variety of ways to solve housing problems.

The distribution of housing demand for 1000 inhabitants according to the regional aspect reveals that the problem of social home is most expressed in town area, especially in Vilnius city. The number of applicants in towns comprises 3.1 per 1000 inhabitants and 3.6 - in Vilnius city.

This number in district area comprises only 1.95 . Apparently, this type of distribution is conditioned by the greater population concentration in certain areas, inner migration, and the greater demand for homes in towns.

Therefore, the development of social home and distribution of funds have to be planned in proportion to the distribution of demands.

\section{CONCLUSIONS}

- According to the data obtained from the registration, almost $99 \%$ of population in Lithuania resides in traditional homes. 0,04\% (1250) - in the shelter unfit for people to live in (huts, summer-houses etc). They are assigned to the group of homeless population. However, nearly 5,6\% (73000) of households, 200,000 inhabitants own no home and live with their acquaintances, parents or relatives.

- The housing and its quality is essentially different in town and village areas. $79 \%$ of town population resides in the apartment houses, $80,2 \%$ of village population - in individual houses. Living space comprises $21,2 \mathrm{~m}^{2}$ per capita in town area, $25,4 \mathrm{~m}^{2}$ - in village area. Only half of all village households have water supply, bathroom or shower. Approximately 50\% of village households have stove heating system.

- Lithuania belongs to the group of EU member states reflecting the most privatized home system. 95,2\% of all homes are under private ownership (owners are natural persons). State and Local
Governments own 2,9\% of homes, the rest of homes belong to private legal persons.

- New apartment house owners are not prepared to control and maintain common property appropriately. Just a quarter of all apartment houses have established owners' communities.

- The household poll revealed that only $42,8 \%$ of households consider their living conditions to be good. Others consider them as satisfactory or poor. The greatest discontent was revealed in heating effectiveness, utilities, layout, and living space.

- Aiming at a higher level of living conditions it is necessary to consider the increase of the heating effectiveness, the improvement of heat insulation, and the expansion of utilities in the village areas and renovation of the apartment houses as the primary goals.

- The living conditions have improved over the past 5 years for a quarter of all households; however, they have become worse for one fifth of all households. They encompass the households of the elderly, the disabled, unemployed, and other persons with low income. This has been revealed through the social division tendencies.

- The low income inhibits the households from the improvement of their living conditions. The investigation revealed that the range of the households with low income was very large. The lowest income appeared to be 12-15 times different from the highest income.

- The comparison of income distribution and the home rent and purchase prices shows that $34 \%$ of households can afford renting or obtaining homes in the cities. A third of households can claim only a cheap home. Other households can afford obtaining or renting a home in smaller towns or obtaining and purchasing it in cities with the help of State financial support.

- The State financial support for housing makes housing loans available for hou- 
seholds with average income. This trend should continue. - The problem of social home is most relevant in the cities where the number of households having a right to social home is 3,1 per 1000 inhabitants, 1,95 - in regions. Young families comprise a big part of applicants $(30,6 \%)$. Especially it is evident in town areas $(40,6 \%)$. The disabled amount $16,4 \%$.

\section{REFERENCES}

[1] V. Jonaitis, J. Naimavičienè, Analysis of housing sector in Lithuania, International Journal of Strategic Property Management, 7(4), 2003, p. 172-182.
[2] M. Lee, Sustainable Housing Program Development, Vilnius, December 2002.

[3] Lithuanian Free Market Institute, Household Study, September 2002, p. 21-34.

[4] Lithuanian State Land Cadastre and Register, Review of Baltic States Real Estate Market, Autumn 2003, 2003.

[5] Statistics Lithuania, Household Income and Expenditure, Vilnius, 2002 (in Lithuanian).

[6] Statistics Lithuania, Results of the 2001 Population and Housing Census in Lithuania, Buildings and Dwellings, Vilnius, 2002 (in Lithuanian).

[7] Statistics Lithuania, Statistical Yearbook 2002, Vilnius, 2003 (in Lithuanian).

[8] Statistics Lithuania, Stock of Dwellings and Construction 2002, B902, Vilnius, 2002 (in Lithuanian). 